
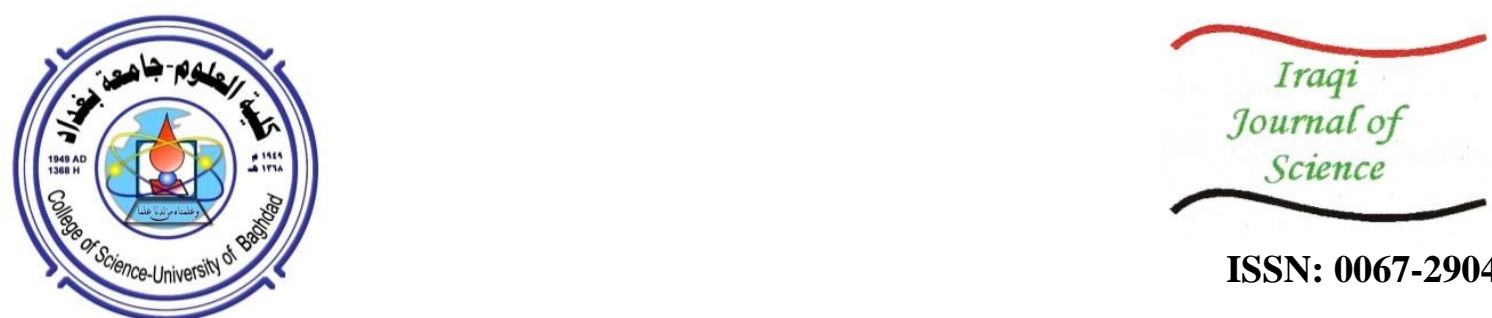

ISSN: 0067-2904

\title{
Structural Reservoir Characterization of Akkas Gas Field, Western Iraq: Implications for Hydrocarbon Recovery
}

\author{
Abdulkhaleq A. Alhadithi \\ Department of Applied Geology, College of science, University of Anbar, Ramadi, Iraq
}

Received: 7/4/2021

Accepted: 7/6/2021

\begin{abstract}
Akkas Field is a structural trap with a sandstone reservoir that contains proven gas condensate. The field is a faulted anticline that consists of the Ordovician Khabour Formation. The objective of this research is to use structural reservoir characterization for hydrocarbon recovery. The stratigraphic sequence of the Silurian and older strata was subjected to an uplift that developed a gentle NW-SE trending anticline. The uplifting and folding events developed micro-fractures represented by tension cracks. These microfractures, whether they are outer arc or release fractures, are parallel to the hinge line of the anticline and perpendicular to the bedding planes. The brittle sandstone layers of the reservoir are interbedded with ductile units of shale. The sandstone layers accommodate the formation of micro fractures that play a major role to increase the secondary porosity. The gas and condensate have been stored mainly through the micro fractures. Two types of drilling have been used for experimental gas production, vertical and horizontal. Horizontal drilling was parallel to both hinge line of the anticline and micro fracture surfaces that was conducted and doubled the gas production of the vertical well multiple times. However, if used the third type of drilling, directional, that is perpendicular to the hinge line and parallel to the beddings of both flanks of the anticline gas production will increase more than the horizontal drilling. The directional drilling will become perpendicular to the fracture surfaces and allow the gas and the condensate to flow into the well from all directions. Additionally, it will reduce the effect of both semi - liquid hydrocarbon condensate and vertical sediment barriers.
\end{abstract}

Keywords: Directional drilling; Akkas gas field; uplift; micro fractures; Iraqi Western Desert

الوصف التركيبي لخزان حقل عكاس الغازي، غربي العراق: واثارها على استعادة الهايدركاربون

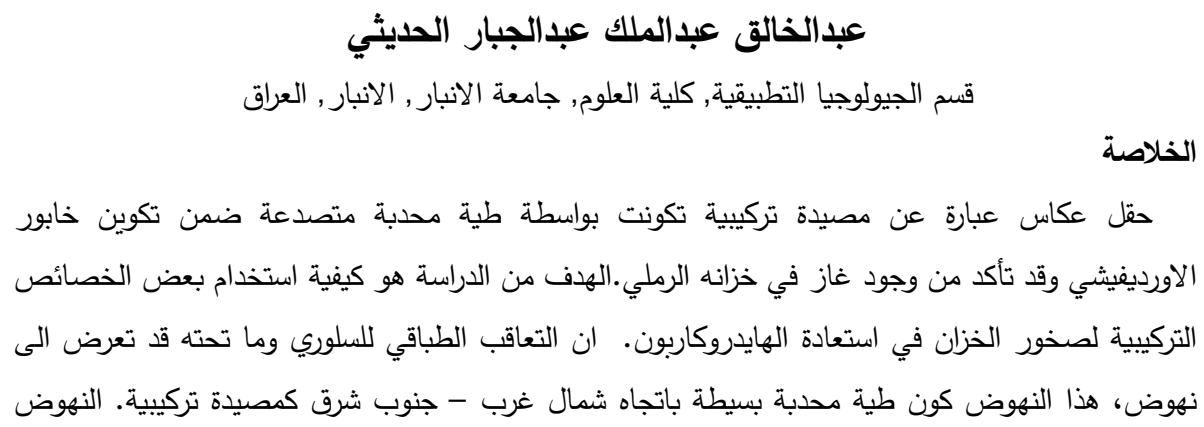

*Email: abdul.6363@uoanbar.edu.iq 


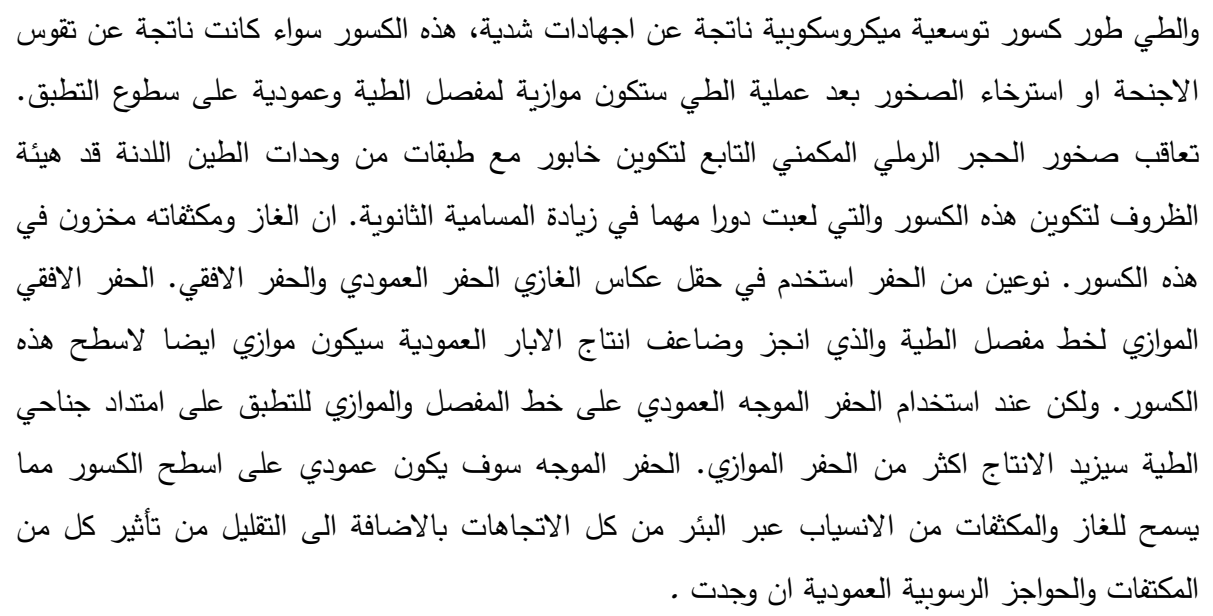

\section{Introduction}

Natural gas can be extracted from deep formations by three methods of drilling of wells, namely vertical, horizontal, and directional. Reservoir properties determine what drilling method should be used. For example, vertical drilling is used where the fractures are horizontal, whereas horizontal drilling is used where the fractures are vertical [1]. A directional drilling (the technique of drilling at an angle) is used to achieve multiple purposes, e.g. side-tracks, multiple sand layers, exploration of wells from a single wellbore, fault controlling, inaccessible locations, salt domes, horizontal drains, relief wells, and onshore and offshore drillings $[2,3]$.

The Lower Paleozoic deep and conventional hydrocarbon reservoirs have become targets of the oil exploration companies in Iraq and neighbouring countries (Syria, Jordan, and Saudi Arabia) during the last decades. So far, no data are available about the Cambrian sequence in Iraq, because neither outcrop nor deep wells are available. However, the stratigraphy of the Ordovician and Silurian deposits, especially the black shale and sandstone layers of the Ordovician sequence and the hot shale of the Lower Silurian, shows availability of the source, reservoir, and cap rocks [4-7].

Akkas gas field is located in the northwest of the Iraqi western desert, near the Syrian border about $30 \mathrm{~km}$ south of Al-Qaim city (Figure 1). Sandstone layers of the upper part of the Ordovician Khabour Formation are composed of a reservoir rocks that were subjected to digenesis, compaction, and cementation by antigenic minerals, due to burial, pressure, and temperature. These factors led to the reduction of the primary porosity and permeability. In contrast, micro fractures play an important role in increasing the secondary porosity and permeability of the sandstone reservoir rocks, by rations of $10 \%$ and $500 \mathrm{mD}$, respectively [6, 8, 9, 10]. Six vertical wells, Akk-1 to Akk-6, and some horizontal wells were drilled by the North Oil Company. The horizontal wells were drilled parallel to the hinge line of the Akkas structure, which doubled the production of the gas multiple times [11].

The micro factures in the competent sandstone beds of the Khabour Formation are vertical and parallel to each other [11]. The fractures are mostly developed due to tectonic impacts. The tectonic fractures are systematic, parallel to sub parallel, and evenly spaced to each other. This article focuses on how the directional drilling increases gas production due to the presence of some potential properties. Only vertical and horizontal drilling in Akkas gas field, but the structural characteristics of the reservoir rocks in the Akkas filed could increase natural gas production by using directional drilling. 


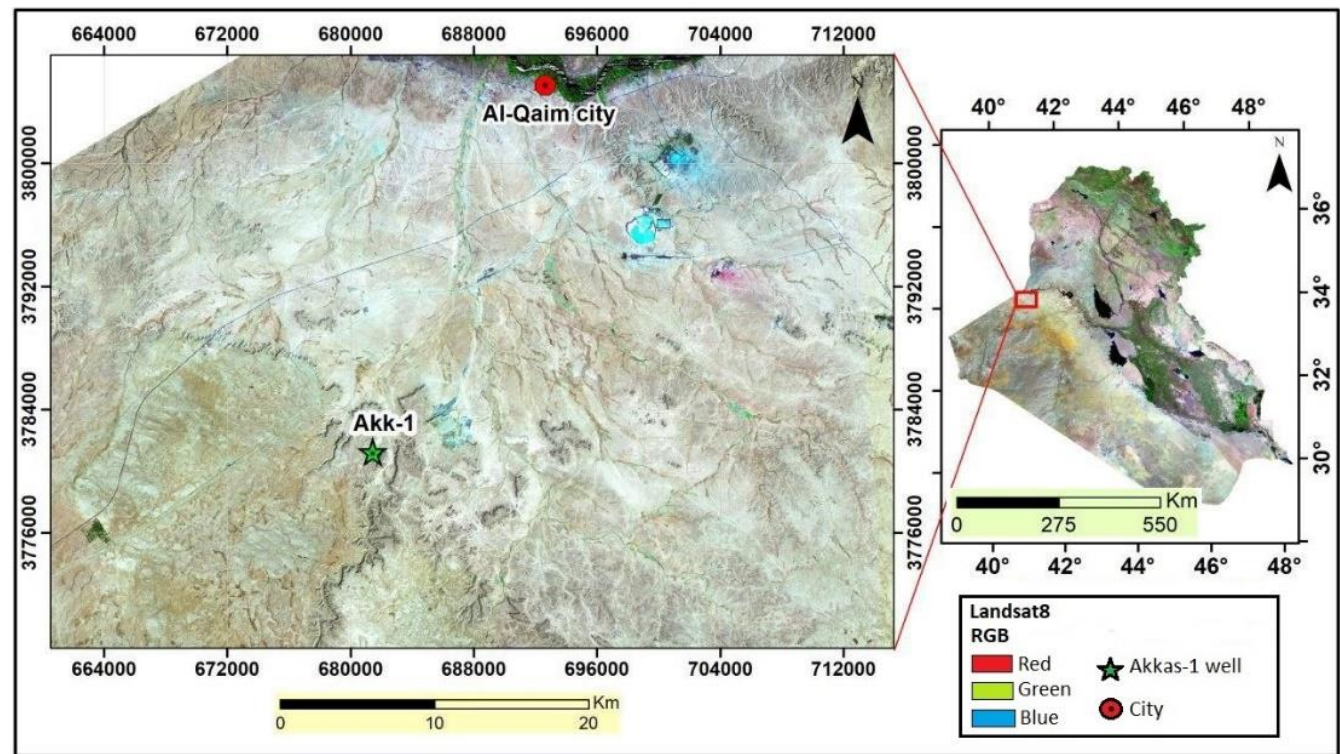

Figure 1-Location map of the study area in which exploration well AKK-1 is shown (Landsat 8 Satellite image RGB 642)

\section{Geological Setting}

The stratigraphic sequence of the Iraqi Western Desert displays several unconformities with general domination of siliciclastic sediments and carbonate deposits of Paleozoic and Mesozoic, respectively. The Paleozoic sequence was deposited in a shallow marine whereas the carbonates of the Mesozoic were deposited with interspersed clastic episodes. The Cenozoic sequence shows gradual retreat of the sea and final transition to the continental conditions $[12,13]$.

The Akkas gas field is a NW-SE trending anticlinal structural trap. There is a main graben to the northeast of the anticline and parallel to it $[6,10,11]$. The exploratory Akkas-1 well is the deepest well, but it does not reach the lower contact of the Khabour Formation. The total depth of the well is $4238 \mathrm{~m}$. In the well, the total thickness of the Ordovician Khabour Formation is $1913 \mathrm{~m}$. It consists of black shale beds with variable thickness, white and grey sandstone, and siltstone (Figure 2). The Khabour Formation is sealed unconformably by the lower beds of the Silurian Akkas Formation hot shale. The hot shale layers are considered source and cap rocks simultaneously [4]. Four main unconformities exist throughout the stratigraphic sequence, especially between the Late Ordovician and the Early Silurian due to a hiatus in the Hirnantian times that resulted from the association of sea-level drop-in with the glaciation of Gondwana [10]. Additionally, the sequence is missing the Lower and Middle Devonians as a result of Caledonian orogeny and missing the Middle and Upper Carboniferous due to the Hercynian orogeny [14, 15]. The latter is a hiatus that includes the Upper Permian, Triassic, Jurassic, and the Lower Cretaceous, with a preserved remnant of $116 \mathrm{~m}$ of red beds. The main unconformities of the Akkas area reflect either no deposition or erosion of a large amount of the stratigraphic sequence due to high tectonic activities, especially the impact of the vertical movement of basement blocks due to the Caledonian and Hercynian orogenies that developed uplift and subsidence.

Tectonically, the area of interest is located within the inner Arabian platform [16]. The Iraqi Western Desert, where the Akkas gas field is located, and its boundary were subjected to many types of deformations, such as extension [12], strike-slip [12, 17, 18], and uplift [4, 7, $12,19]$. The uplift caused by the vertical movements of the basement blocks, which developed the gas and/or oil field, occurred not only in the Iraqi Western Desert, but also in many surrounding areas, such as Alan field in the Mosul high [20]. The uplift movement 
plays an important role in developing oil and gas fields as a result of producing traps due to elevating specific areas that are higher than the surroundings, which facilitates the up-dip migration of gas and oil toward the traps [20].

The primary porosity and permeability of the hard sandstone reservoir rocks of the Akkas field, which were destroyed due to diagenesis processes, are intergranular. In contrast, the secondary porosity and permeability are intragranular, leading to increase the levels of these two petrophysical properties to $10 \%$ and $500 \mathrm{mD}$, respectively [21]. The secondary porosity and permeability are due to micro fractures of quartz grains and dissolution of feldspar. The feldspar represents a small percentage, about $20 \%$, of the hard sandstone, whereas quartz represents a high percentage of approximately $80 \%$ [21]. The micro fractures occasionally run through more than one quartz grain to pass the solid matrix between them [11], which indicate that the secondary porosity and permeability are dependent on the micro fractures.

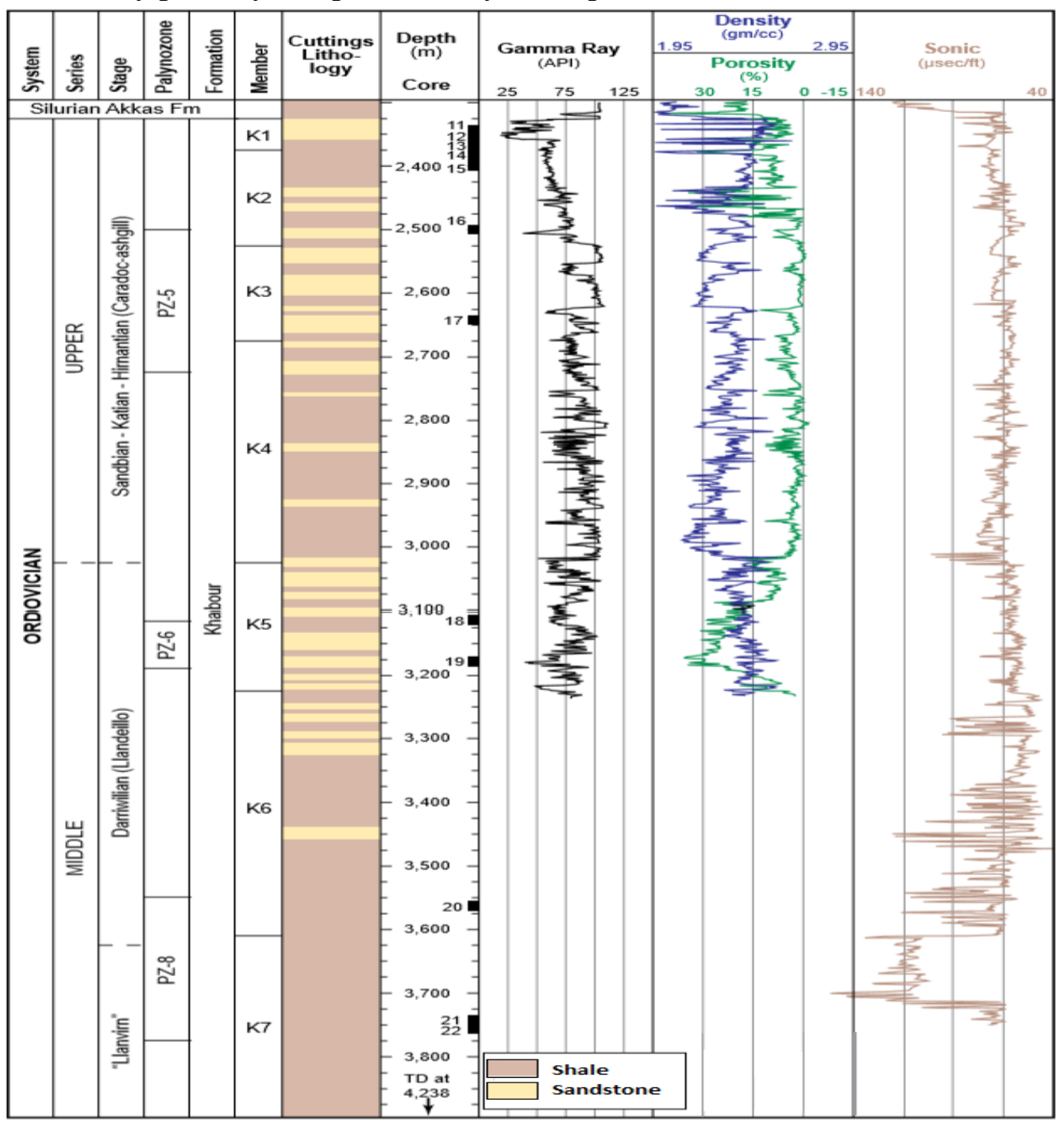

Figure -2 Khabour Formation in Akk-1 well after [10]. The brittle sandstone layers are interbedded with ductile units of shale. The sandstone layers accommodate the formation of microfractures.

\section{Materials and Methods}

One scene of Landsat-8 LDCM (Landsat Data Continuity Mission, image 171/36) is used to prepare the location map by using ArcGIS 10.8 software (Figure 1). Several seismic reflection sections were used to show the subsurface structural trap. A section that passes through the Akk-1 well and approximately perpendicular to the Akkas structure is present, 
which gives a good structural view (Figure 3). Four seismic reflectors are picked up; the first reflector is the Tayarat Formation (Late Cretaceous), while the second reflector is the Red Bed which consists of $116 \mathrm{~m}$ red marl and clay, overlies the Ga'ara Formation (Lower - Upper Permian), and underlies the Tayarat Formation. The Red Bed unconformity represents the hiatus of the lower Permian, Triassic, Jurassic, and the Lower Cretaceous [10]. The third reflector is within Akkas Formation (Silurian), and the fourth reflector is the upper contact of Khabour Formation (Ordovician). The reflectors are identified by using well velocity survey, synthetic seismogram data, and the geological section of Akkas well-1. All the above reflectors are unconformity surfaces except within Akkas reflector [8, 10, 22].

A structural map of the Ordovician Khabour Formation is drawn by using the depth provided in the Akkas wells and data from the seismic sections (Figure 4). The map is drawn by using ArcGIS 10.8 but the contour lines are drawn by hand because some normal faults are present and to explain why the gas is missing in Akk-6 well. A normal fault is delineated in the southeastern plunge that locates between Akk-4 and Akk-6 wells (Figure 4).

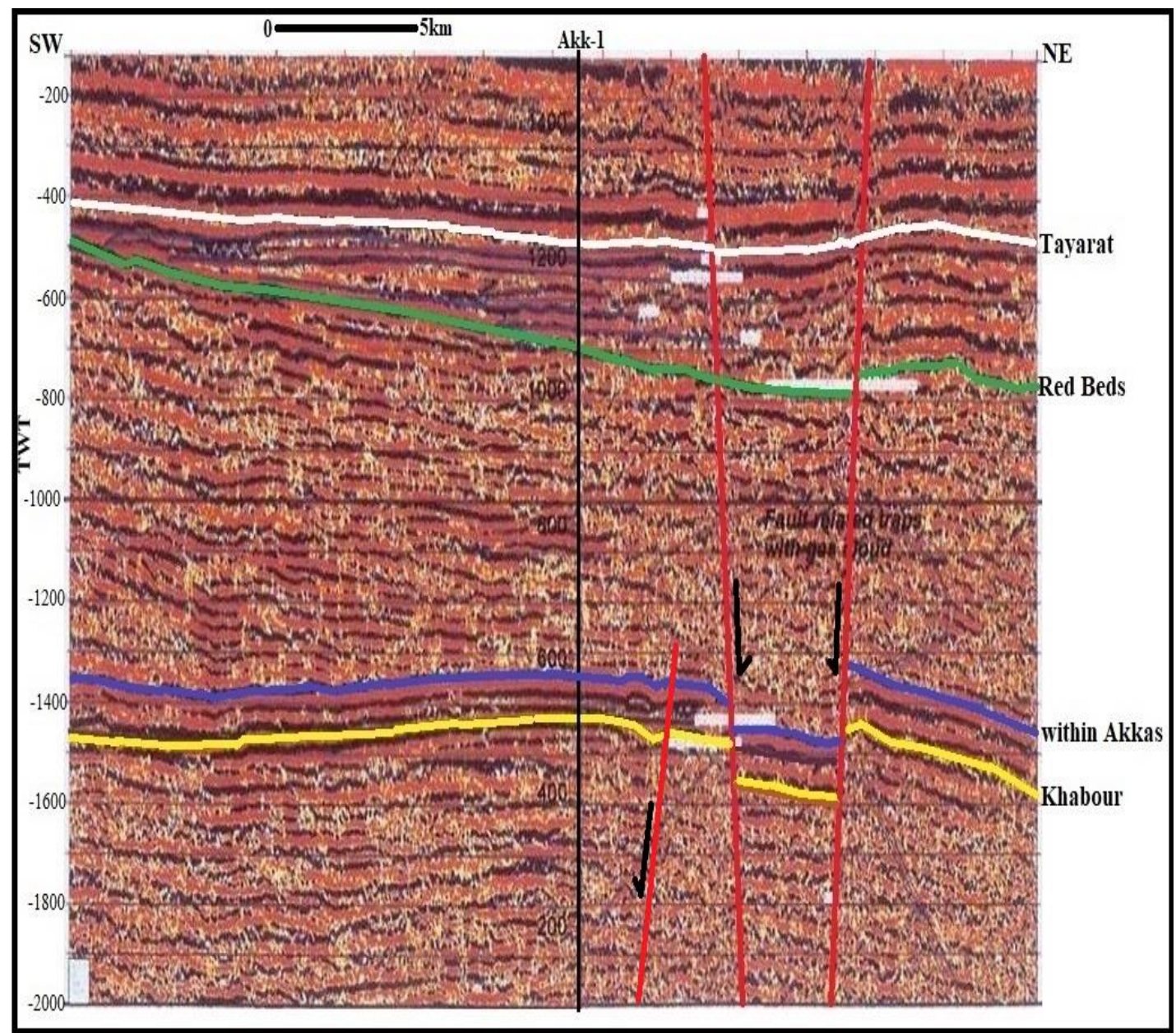

Figure 3-Seismic section As -20 


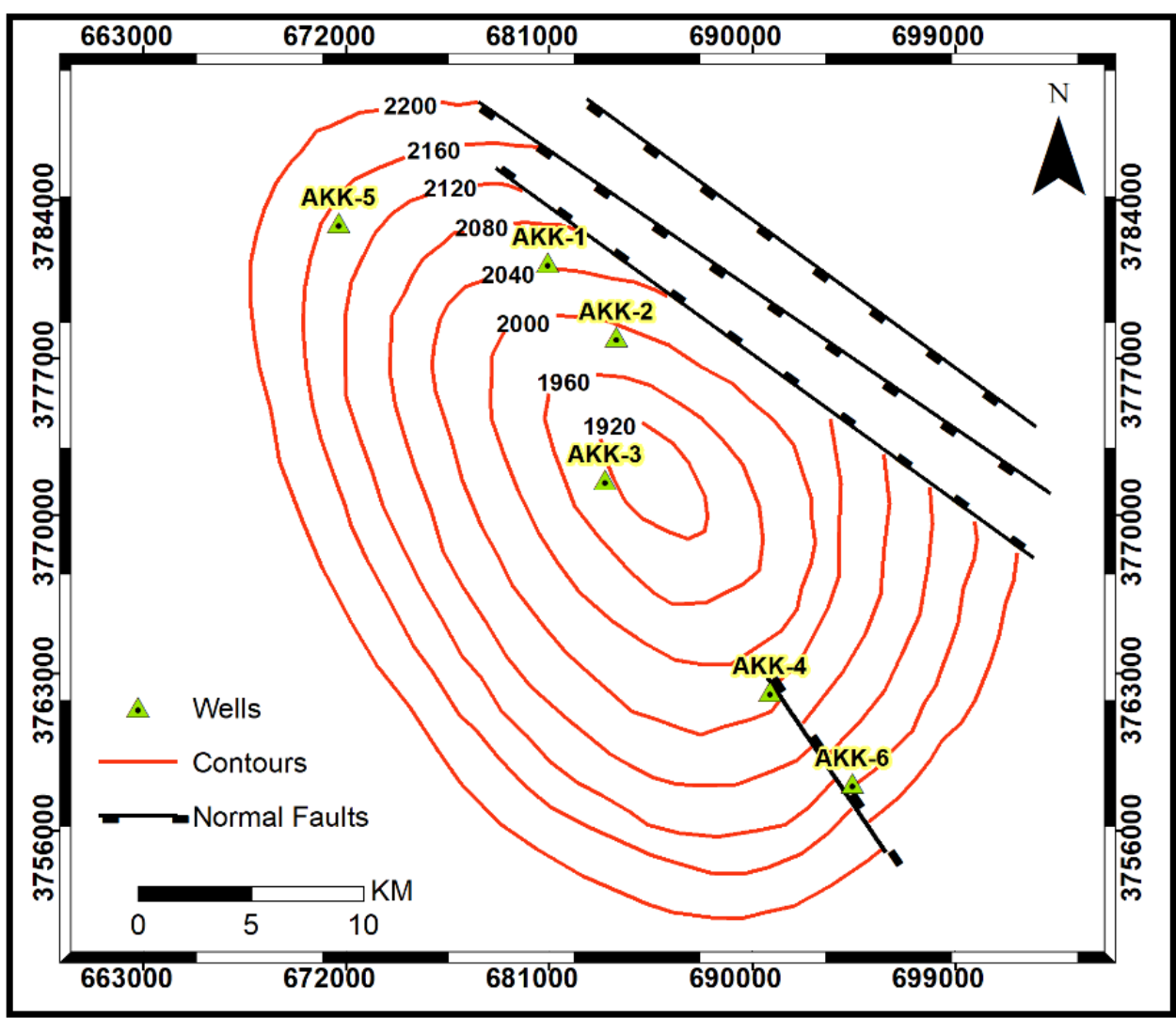

Figure 4-Structural map of upper contact of Khabour Formation, modified from [6]

\section{Results and Discussion}

Horizontal or low angle drillings are very important to reduce the number of vertical wells, increase the production, and achieve the ultimate recovery of the entire field [23]. However, the directional drilling at a specific angle plays an important role, especially if that fits with some structural characteristics of reservoir rocks, e.g., the attitude of the fractures or microfractures.

The Akkas unconformity surface represents about 35-million-year hiatus [10]. The unconformity is due to Caledonian Orogeny [15]. The seismic section As-20 (Figure 4) and the other sections show that the geometry and architecture of the Akkas reflector downward are similar. The sequence from Akkas Formation downward was subjected to uplift. The uplift developed a gentle anticline, i.e. the Akkas structure or trap. The hinge line of the anticline is NW - SW trending. The dip of the north-eastern and south-western flanks, as determined by using the three-point problems technique, is about $2^{\circ}$, whereas the northwestern plunge is $1^{\circ}$. The seismic section displays a symmetrical graben bounded by a pair of high angle normal faults having approximately equal displacement. The graben reaches to the earth's surface where Euphrates Formation (Early Miocene) is exposed. The graben was developed due to the stretching when the northeast margin of the Arabian Plate behaved as a passive margin during the upper Cretaceous. The stretching was left thickening between the Red Beds and Tayarat reflectors (Upper Cretaceous formations). The thickening increases toward northeast to meet Anah Graben. The thickening during the Upper Cretaceous formations is not found only in Akkas Graben but also in Anah Graben, where it reaches 2000 $\mathrm{m}$ thick in the Upper Cretaceous formations [12] and Tayarat graben in Al-Jazira Area north of Akkas graben [24].

The uplifting and gentle folding developed the outer arc's microfractures at the beginning of the folding and released micro fractures after the folding processes. Surfaces of both types of micro fractures are perpendicular to bedding planes and parallel to the hinge line. In gentle 
folded sedimentary rocks, the strata contain a joint set that is at a high angle to the bedding and the fan around the fold, which is roughly parallel to the regional fold hinge (release) [25, 26]. Stylolite exists through the sandstone cores of Khabour Formation [21], with the presence of brittle sandstone layers interbedded with ductile substance shale units (Figure 2). This supports the possibility that a tangential longitudinal strain folding has happened through the sequence of Khabour Formation that contributes to the development of the high angle dense micro fracture through the sandstone layers by uplifting and folding the sequence of Akkas field. The tangential longitudinal strain folding (Figure 5) shows the along-depth variation of the strain, which is compressional below, and extensional above, the neutral surface. The existence of detachment layers may repeat these features [27].

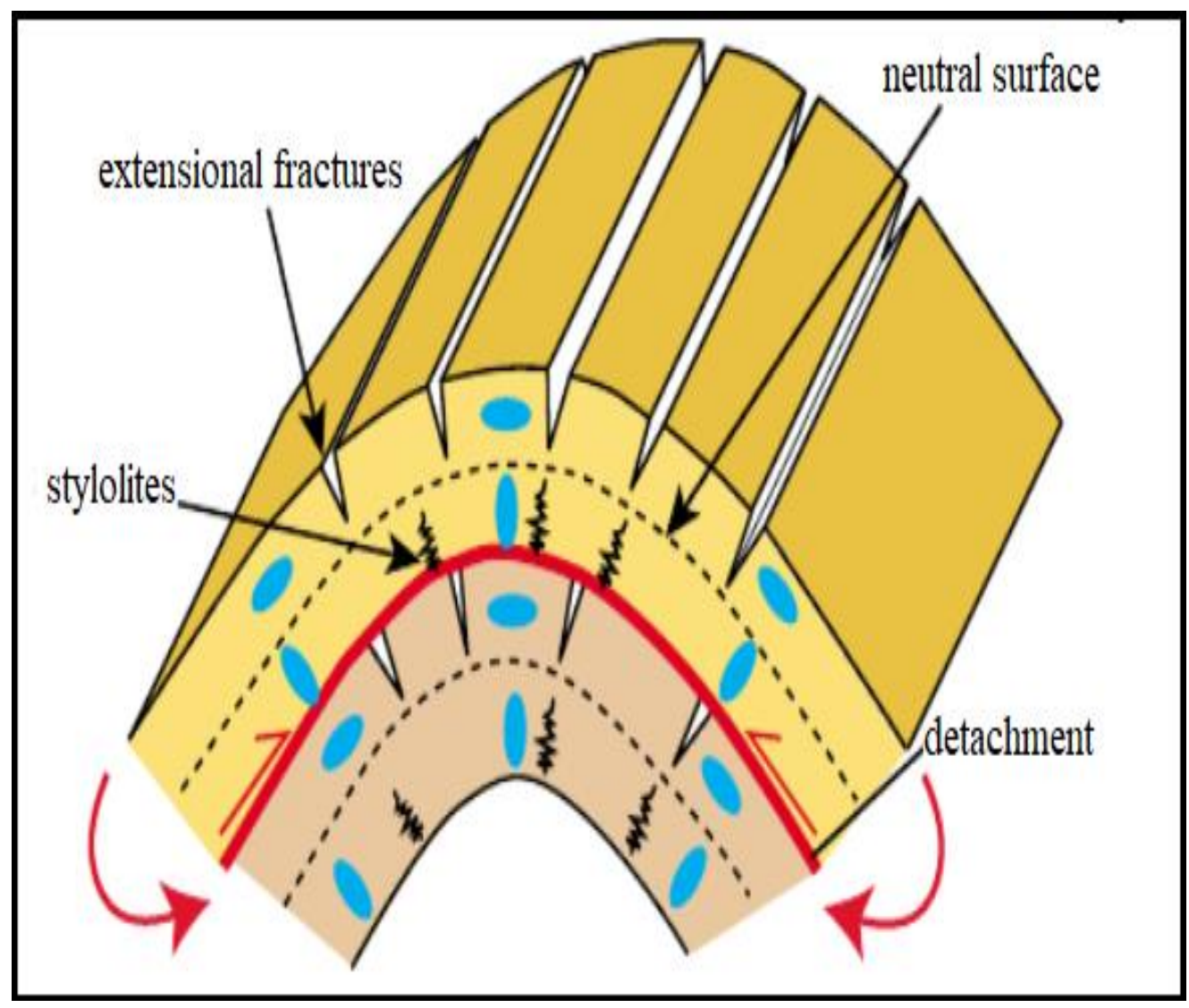

Figure 5-Extensional fractures are developed in the hard layer, e.g. sandstone, while detachment occurs through the ductile layer, e.g. shale [27].

The stretching phase that developed the grabens and normal faults of Akkas field during Late Cretaceous and led to the stratigraphic thickening between red bed and Tayarat reflectors has also developed vertical fractures parallel to normal fault surfaces. Vertical fractures are formed by high angle normal faults [28]. The set of normal faults, grabens, strike-parallel joints or micro fractures, and vertical fractures [28] are parallel to each other and have a NWSE trending. All these deformational structures increase the secondary porosity and permeability of Akkas reservoir sandstone layers.

There is a relationship between the method of drilling and the type of the naturally fractured reservoir to be drilled; vertical drilling is performed to explore gas - bearing horizontal fractured reservoirs, while horizontal drilling is for gas - bearing vertical fractured reservoirs [29]. However, directional drilling through the flanks of the anticline in Akkas field is considered as a very good method. It occurs perpendicularly to the strike of the flank layers and parallel to the bedding planes. The directional drill becomes perpendicular to 
microfracture surfaces (Figure 6). The microfracture surfaces are parallel to sub parallel to each other that become effective, especially if the gas-bearing layer has a good thickness. The thickness of gas reservoir column in Akkas field is approximately $80 \mathrm{~m}$ [6]. The directional drilling will be achieved by making a cut off from the high angle to the bedding and fan around the fold flanks that has micro fractures perpendicular to them. Natural gas production will be increased dramatically. The condensate phase also exists in Akkas field that behaves as pressure decline, which has zero or very low mobility, except around the wellbore [30]. Directional drilling reduces the effects of both condensate and possible vertical sediment barriers.

The high production of the gas in Akk-3 well is not only due to the location of the well near the crest of the anticline, but also due to the normal fault shown in the seismic section As-20, which plays an important role to supply the gas to the well. Additionally, the high fracture intensity in the hinge zone, due to maximum curvature of the folding, has also a role.

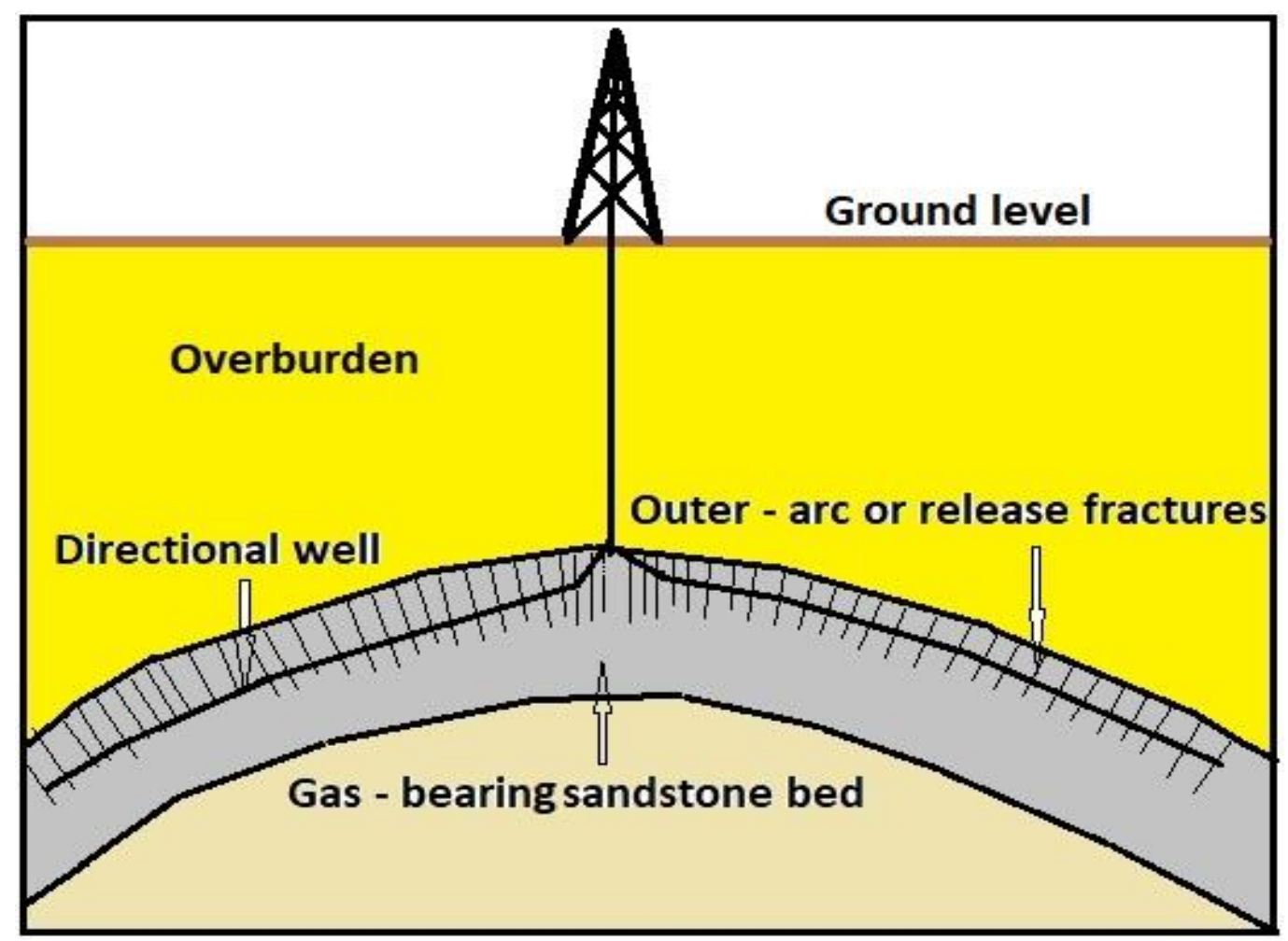

Figure 6-Directional drilling for gas - bearing folded bed which has outer - arc or/and release fractures due to the folding.

\section{Conclusions}

The Akkas gas field is a structural trap that has been developed due to the uplifting and folding of the stratigraphic sequence from the basement to the upper contact of Akkas Formation. The structural trap is an anticline, which has a NW-SE trending, with dips of the north-eastern and south-western flanks of about $2^{\circ}$ and of the north-western plunge of about $1^{\circ}$. The uplifting and folding processes have developed sets of outer arc and release microfractures parallel to the hinge line and perpendicular to bedding planes. The phase of NE-SW stretching of the north-eastern Arabia's passive margin has developed grabens with NW-SE trending fractures parallel to the microfractures. The stratigraphic sequence of the Ordovician Khabour Formation is represented by an alternation of hard sandstone with shale 
that contributes to develop the high angle dense micro fracture through the sandstone layers by uplifting and folding the sequence of Akkas field.

Directional drilling parallel to the bedding and perpendicular to hinge line, in both flanks, especially the SW flank, should be made perpendicular to the micro fracture surface. This will increase natural gas production to levels higher than those achieved by the horizontal drilling parallel to the hinge line of the Akkas structure. High gas production in the Akk-3 well is not only due to the location of the well near the crest, but also due to structural properties found there, such as the normal fault near the well and the intense micro fractures due to the maximum curvature in the hinge zone.

\section{References}

[1] W. L. Watney, "Horizontal Drilling - Technology Review, Current Applications, and Petroleum Resources," Kansas Geological Survey, Lawrence, KS66047, 2016.

[2] T. Ma, P. Chen, and J Zhao, "Overview on vertical and directional drilling technologies for the exploration and exploitation of deep petroleum resources," Springer International Publishing Switzerland, pp. 365-395, August 2016, doi: 10.1007/s40948-016-0038-y.

[3] R. Ahmadi, "Directional drilling (course for professional master)," ISSTAG, ResearchGate, November 2018, https://www.researchgate.net/publication/328879733.

[4] A. S. Alsharhan, and A. E. M. Nairn, ". Sedimentary Basins and Petroleum Geology of the Middle East," second impression, Elsevier Science B.V., 2003

[5] A. A. M. Aqrawi, J. C. Goff, A. D. Horburu, and F. N. Sadooni, "The Petroleum Geology of Iraq. Printed in Great Brittain by Cambrian Printers, 2010.

[6] T. K. Al-Ameri, "Palynostratigraphy and the assessment of gas and oil generation and accumulations in the Lower Paleozoic, Western Iraq" Arab J Geosci, vol. 3, pp.155-179, 2010, doi: 10.1007/s12517-009-0060-2.

[7] S. Z. Jassim, "The geological architecture of the Arabian plate" A PowerPoint presentation to the oil exploration company, ministry of oil, Baghdad, 2019.

[8] A. H. Al-Hadidy, "Paleozoic stratigraphic lexicon and hydrocarbon habitat of Iraq," GeoArabia, vol. 12, no. 1. Gulf PetroLink, Bahrain, 2007.

[9] G. H. Al-Shara'a, "High resolution sequence stratigraphic modeling facies architecture and petroleum system of Paleozoic sequences in western and southwestern desert of Iraq - Correlated with adjacent domains", unpublished $\mathrm{PhD}$ thesis, University of Baghdad, 2008.

[10]A. H. Al-Hadidy, "Paleozoic stratigraphic lexicon and petroleum system in Iraq," PRDC, ministry of oil, Iraq, July 2018.

[11]N. H. Alhadithi, "Hydrocarbon assessment in Paleozoic sequence of Iraqi Western Desert," North oil company, A PowerPoint presentation to the University of Anbar, 2019.

[12]S. F. A. Fouad, "Tectonic and structural evolution of Iraqi Western Desert," special issue, Iraqi bulletin of geology and mining, 2007.

[13]M. Y. Tamar-Agha and M. A. Basi, "The Sedimentology of the Late Campanian-Maastrichtian Sequence, Southwestern Iraq," Iraqi Journal of Science, vol. 62, no. 3, pp: 897-911, 2021. DOI: 10.24996/ijs.2021.62.3.21, 2021.

[14]N. Marouf, "Hydrocarbon possibilities in Al-Anbar governorate, structure and basin evaluation" A PowerPoint presentation to the University of Anbar, 2019.

[15]N. M. S. Numan, "A plate tectonic scenario for the Phanerozoic succession in Iraq" Iraqi Geological Journal, vol. 30, no. 2, pp. 85-119. October, 1997

[16]S. F. A. Fouad, "Tectonic map of Iraq scale 1: 1000 000, GEOSURV. Vol.11, No.1, 2015, part 2, p1-7, 2015.

[17] A. A. Alhadithi, and E. A. M. Al-Heety, "Behavior of Abu-Jir Fault Zone in Al-Thirthar Valley and near Habbaniya Lake Areas - Comparative Study Using Seismic Reflection Sections" J. of University of Anbar for pure science, vol.11, no.1, 2017.

[18]A. A. Alhadithi, "Development of depressions (sag ponds) south of Heet, west of Iraq" Egy. J. Pure \& Appl. Sci., vol. 55, no. 1, pp. 15-21, 2017.

[19]S. Z. Jassim, and J. C. Goff, "Geology of Iraq” First edition. Printed in the Czech Republic, 2006. 
[20]N. H. Alhadithi, and A. A. Alhadithi, "Differential entrapment of charged hydrocarbon in Alan field, northern Iraq" Iraqi Geological Journal, vol. 53, no. 2A, pp. 68-76, august 2020.

[21] A. H. Al-Hadidy, "Lithofacies, petrography and minerology of Ordovician Khabour Formation in the well Akkas-1, west Iraq," unpublished MSc. thesis, University of Mosul, 1997.

[22]F. H. K. Al-Jubouri, A. H. Youkhanna, M.A. Al-Ruba'I, and A. I. Al-Sammarai, "The Akkas Formation: A new name for a Paleozoic (Silurian) Lithostratigraphic Unit in Iraq," Iraqi Geol. Jour. vol.30, no.1, 1997.

[23]H. N. Akangbou, M. L. Burby, and G. G. Nasr, "Effectively optimizing production of horizontal wells in homogeneous oil reservoir," University of Salford, 2016, https://usir.salford. ac. uk/id/eprint/41090/

[24]N. A. Al-Ridha, and H. J. Al-Khafaji, "Stratigraphic and Structural Study of Khlesia Region Using 2D Seismic Data - North Western Iraq" Iraqi Journal of Science, vol. 60, no.2, pp: 277-289, 2019. DOI: 10.24996/ijs.2019.60.2.9.

[25]J. G. Ramsay, and M. Huber, "Folds and fractures: The tectonic of modern structures geology," v.2, New-York Academic Press, 1987.

[26]V. D. Pluijm, and S. Marshak, "Earth structure. An introduction to structural geology and tectonics," Second edition. 2004.

[27]J. G. Ramsay, "Folding and Fracturing of Rocks" McGraw-Hill, New York. 1967.

[28]K. R. McClay, "Structural geology of petroleum exploration," 2000.

[29]Ma T, Chen P, Yang CH, Zhao J 201. "Wellbore stability analysis and well path optimization based on the breakout width model and Mogi-Coulomb criterion" J Petrol Sci Eng, vol. 135, pp. 678-701, 2015.

[30]E. C. Dahlberg, “Applied Hydrodynamics in Petroleum Exploration” New Yourk: Springer Verlag. 1982. 